\title{
SISTEM INFORMASI PENCATATAN PENGADUAN DAN KELUHAN DI UNIT LAYANAN PELANGGAN PT. PLN SELATPANJANG
}

\author{
Zulfikri \\ Manajemen Informatika, AMIK Selat Panjang, J1. Terpadu Dorak Selatpanjang \\ email: zulfikrimkom@gmail.com
}

\begin{abstract}
PT. PLN (Persero) Unit Layanan Pelanggan Selatpanjang merupakan salah satu perusahaan listrik milik negara yang dibangun untuk memenuhi kebutuhan listrik di wilayah selatpanjang dan sekitarnya. Sejauh ini proses pencatatan pengaduan dan keluhan masih menggunakan cara manual sehingga membutuhkan waktu yang lebih lama. Pada saat ini ditemui banyak kekurangan-kekurangan yang harus dihadapi seperti buku rusak, hilang dan proses pengarsipan yang di gunakan tidak beraturan yang menjadi penghambat kinerja di bidang Pelayanan Teknik PT.PLN (Persero) Unit Layanan Pelanggan Selatpanjang. Hasil akhir dari penelitian ini berupa sistem informasi pencatatan pengaduan dan keluhan Di PT. PLN (Persero) Unit Layanan Pelanggan Selatpanjang.
\end{abstract}

Keywords: Sistem Informasi, Pencatatan, Pengaduan

\section{PENDAHULUAN}

PT. PLN (Persero) Unit Layanan Pelanggan Selatpanjang adalah perusahaan listrik milik negara yang dibangun untuk memenuhi kebutuhan listrik di wilayah selatpanjang dan sekitarnya. Setiap listrik yang tersalur ke rumah pelanggan tidak semuanya berjalan dengan baik, tentu terdapat gangguan dan keluhan dari pihak pelanggan seperti gangguan rumah padam, MCB KWH meter tidak bisa di naikkan kembali atau rusak, piringan meteran pascabayar tidak bergerak, tombol $\mathrm{KWH}$ meter tidak bisa di tekan, KWH meter gagal di masukan pulsa, ID pelanggan atau nomor meter terblokir, kabel sambungan rumah putus atau tertimpa pohon, voltase tidak stabil atau hal-hal lain yang menyebabkan terganggunya penyaluran tenaga listrik ke rumah pelanggan. Apabila hal ini terjadi maka pelanggan bisa melakukan pengaduan ke call center PLN 123.

Apabila pengaduan sudah di lakukan maka call center pusat akan mengirim gangguan kepada unit kerja pelayanan teknik terdekat dengan lokasi area aduan di lakukan. Tim operator di unit kerja pelayanan teknik terdekat dengan lokasi area aduan akan meneruskan gangguan tersebut ke tim pelayanan gangguan, apabila pekerjaan sudah selesai tim operator akan melakukan pencatatan penyebab gangguan dan keluhan dari informasi petugas gangguan menggunakan buku. Jika hal yang tidak diinginkan terjadi seperti buku rusak ataupun hilang maka ini akan menjadi penghambat kinerja di bidang Pelayanan Teknik PT.PLN (Persero) Unit Layanan Pelanggan Selatpanjang. Selain itu jika terjadi pergantian karyawan di bagian operator, resiko kehilangan dan susah ditemukan data yang akan di cari jauh lebih besar di mana proses pengarsipan yang di gunakan tidak beraturan dan penyimpanan buku pencatatan gangguan disimpan secara pribadi sehingga hal ini akan menjadi penghambat kinerja karyawan yang baru di bagian operator dalam membuat laporan.

Untuk mengatasi permasalahan tersebut, maka peneliti bermaksud melakukan penelitian merancang sistem informasi pencatatan pengaduan dan keluhan di PT. PLN (Persero) Unit Layanan Pelanggan Selatpanjang sehingga mengurangi resiko kehilangan data dalam 
pencatatan pengaduan dan keluhan pelanggan.

\section{METODE PENELITIAN}

Dalam menyelesaikan penelitian ini, penulis mengumpulkan data-data dengan beberapa metode antara lain :

1. Wawancara

Melakukan wawancara dengan pegawai di bidang Operator Pelayanan Teknik yang langsung berhubungan dengan proses penginputan data gangguan dan keluhan untuk memperoleh data-data yang akurat.

2. Observasi

Melakukan pengamatan secara langsung saat melakukan penelitian di bagian operator untuk mengamati dan mencatat segala sesuatu yang berhubungan dengan pencatatan gangguan dan keluhan sehingga data yang di terima akan lebih akurat karena bersumber langsung dari bagian yang menjadi sasaran penelitian.

3. Studi Pustaka

Meliput, mencari, membaca, dan menelaah laporan-laporan penelitian dan bahan pustaka yang membuat teori-teori yang relevan dengan penelitian yang akan dilakukan.

4. Studi Internet

Pencarian data untuk melengkapi data penulisan yang dibutuhkan diambil dari sumber di internet.

\section{HASIL DAN PEMBAHASAN}
A. Konteks Diagram Sistem Informasi Pencatatan Pengaduan dan Keluhan PT. PLN Selatpanjang

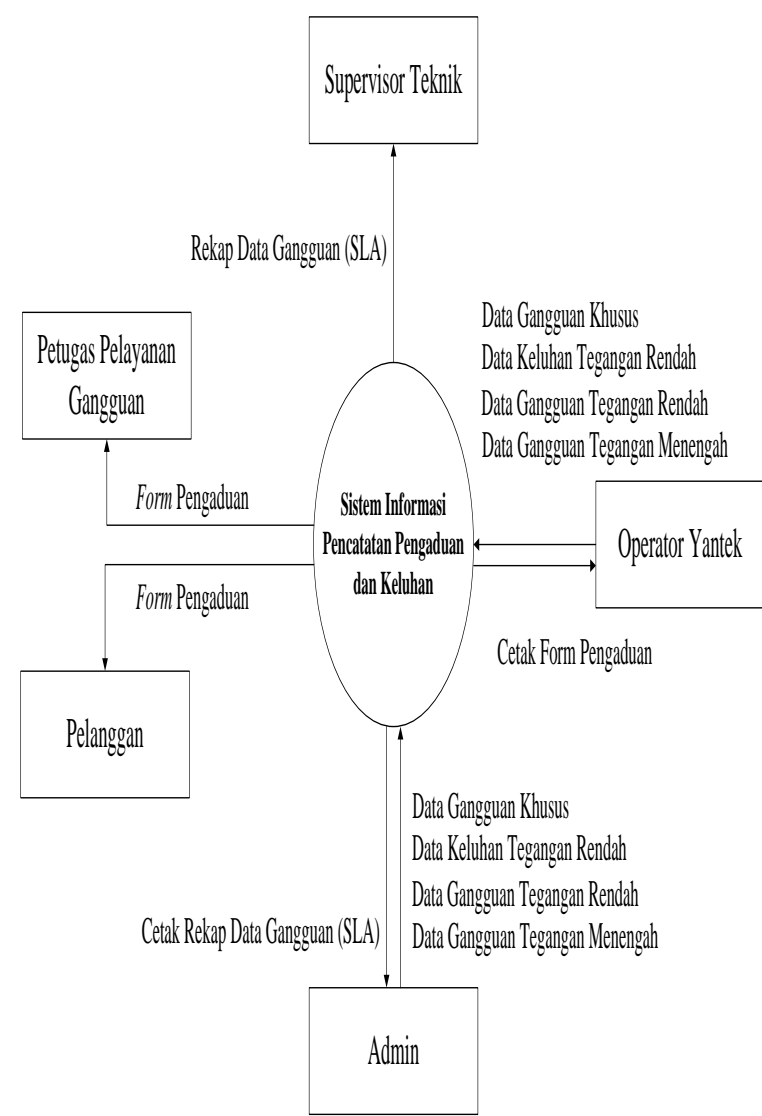

\section{Gambar 1. Konteks Diagram Sistem Informasi Pencatatan Pengaduan dan Keluhan}

Pada Gambar 1 dapat dijelaskan bahwa terdapat suatu proses yaitu operator yantek melakukan proses penginputan berbagai data gangguan dan keluhan seperti, gangguan tegangan rendah, gangguan tegangan menengah, gangguan khusus, dan keluhan tegangan rendah. Data-data tersebut diproses oleh sistem informasi sehingga menghasilkan laporan SLA dan laporan yang kemudian diserahkan kepada supervisor teknik untuk dilakukan pengecekan dan ditandatangani, setelah ditandatangani oleh supervisor teknik maka selanjutnya akan ditandatangan oleh manajer sebagai persetujuan. 


\section{B. Data Flow Diagram Sistem Informasi Pencatatan Pengaduan dan Keluhan PT. PLN Selatpanjang}

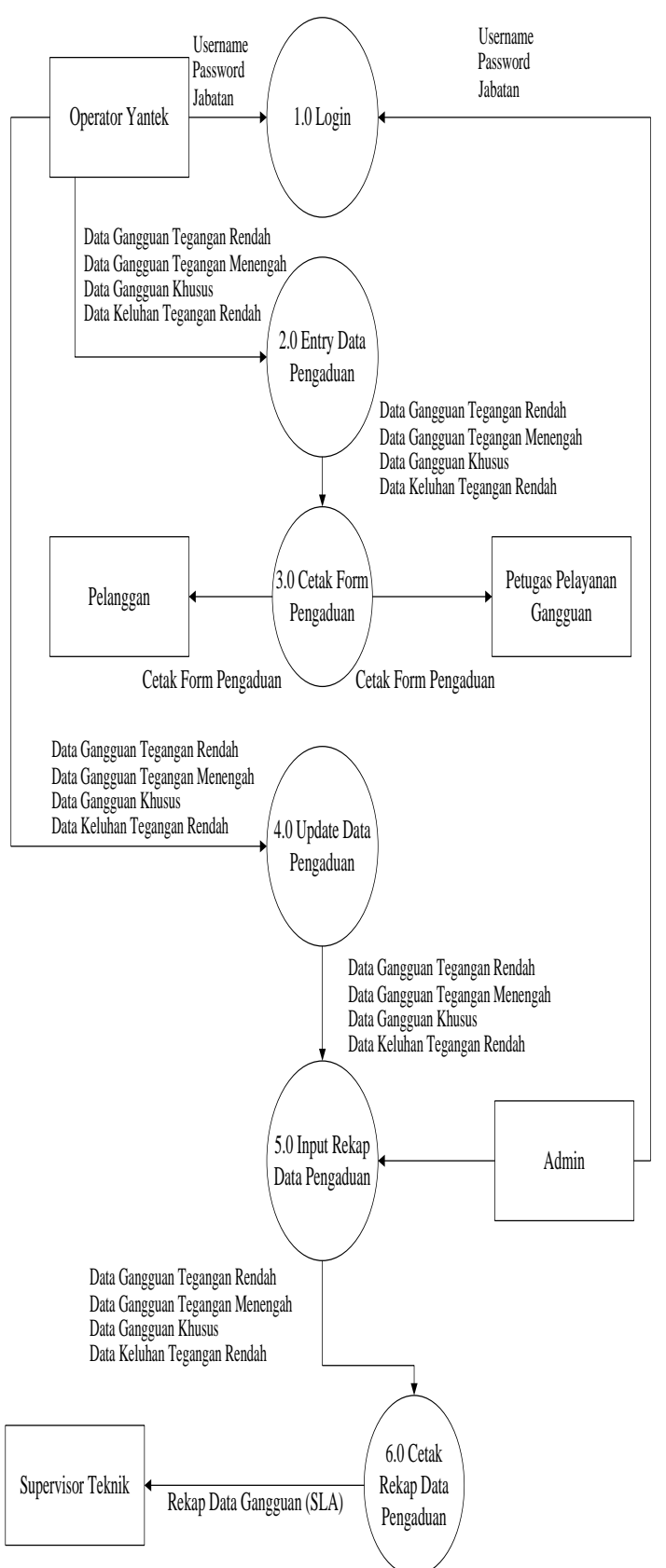

\section{Gambar 2. Data Flow Diagram Level 0}

Pada Gambar 2 data flow diagram level 0 dapat di jelaskan bahwa terdapat proses yaitu operator yantek dan admin harus login terlebih dahulu, kemudian operator yantek menginput data pengaduan , setelah di input data tersebut di cetak dan diserahkan kepada pelanggan dan petugas pelayanan gangguan. Kemudian Operator yantek akan menginput data lapangan . pada proses berikutnya petugas admin akan menginput rekap data pengaduan yang kemudian di cetak sehingga berbentuk rekap data gangguan SLA dan diserahkan kepada supervisor teknik dan manajer

\section{Hasil Implementasi Sistem 1. Tampilan Login}

Tampilan intro merupakan halaman awal yang muncul pada saat aplikasi dibuka yang bisa dilihat pada Gambar 2 .

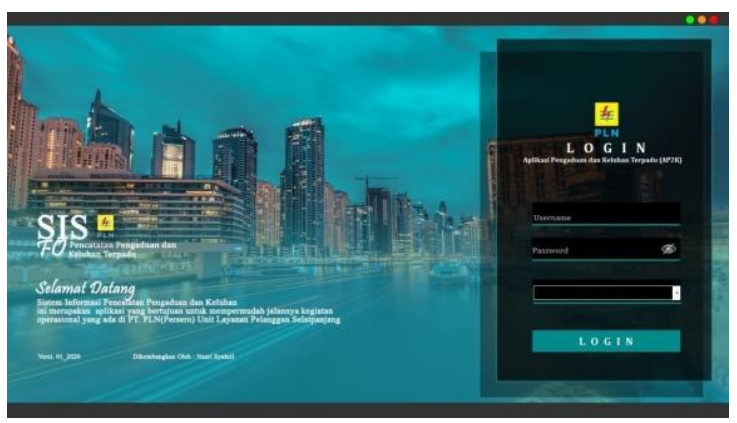

Gambar 3. Tampilan Login

\section{Tampilan Menu Utama}

Tampilan menu utama merupakan pilihanpilihan menu pada aplikasi yang dapat dilihat pada Gambar 3.

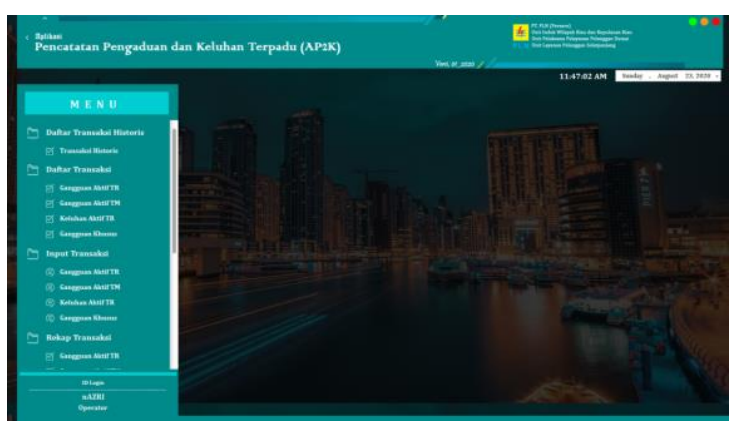

Gambar 4. Tampilan Menu Utama

\section{Tampilan Gangguan Aktif Tegangan Rendah}

Form input transaksi gangguan aktif tegangan rendah pada Gambar 5 merupakan form yang digunakan untuk menginput data pengaduan pelanggan yang menjadi permasalahan dalam kategori gangguan tegangan rendah. 


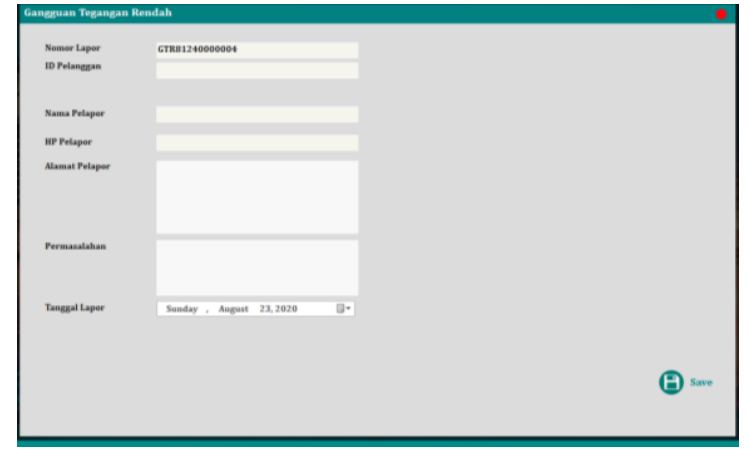

Gambar 5. Tampilan Gangguan Aktif Tegangan Rendah

\section{Tampilan Keluhan Aktif Tegangan Rendah}

Form input transaksi keluhan aktif tegangan rendah pada Gambar 6, merupakan form yang digunakan untuk menginput data pengaduan pelanggan yang menjadi permasalahan dalam kategori keluhan tegangan rendah. Keluhan disebabkan karena adanya pelayanan atau perbaikan oleh petugas yang tidak memuaskan

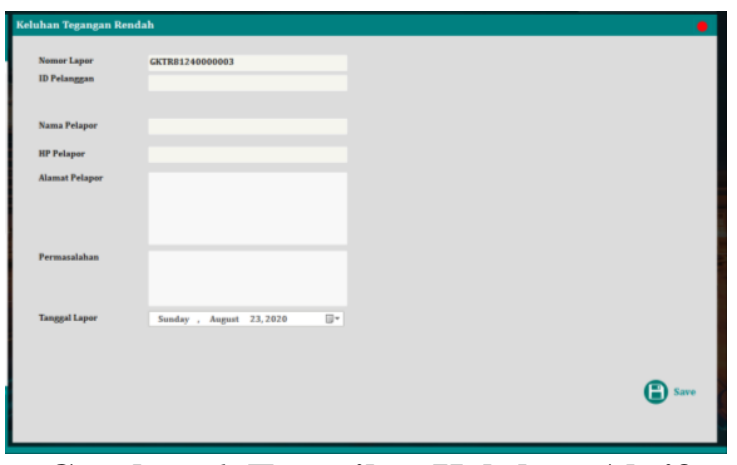

Gambar 6. Tampilan Keluhan Aktif Tegangan Rendah

\section{Tampilan Data Lapangan Gangguan Aktif Rendah}

Form input data lapangan gangguan aktif tegangan rendah pada Gambar 7, merupakan form yang digunakan untuk mengupdate data lapangan gangguan aktif tegangan rendah.

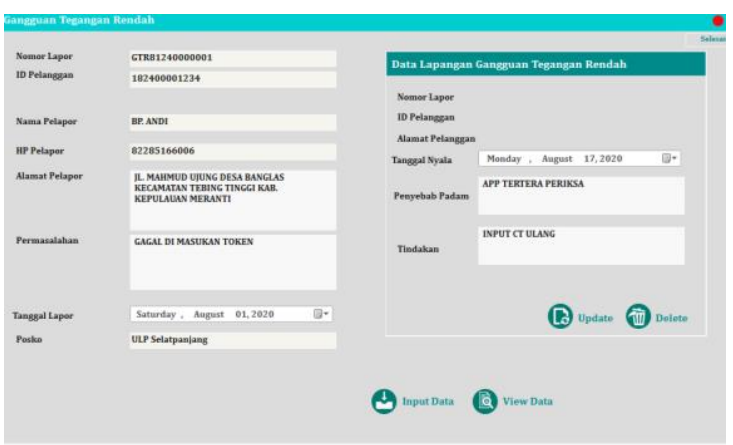

Gambar 7. Data Lapangan Gangguan Aktif Rendah

\section{Data Lapangan Keluhan Aktif} Rendah

Form input data lapangan keluhan aktif tegangan rendah pada Gambar 8, merupakan form yang digunakan untuk mengupdate data lapangan keluhan aktif tegangan rendah.

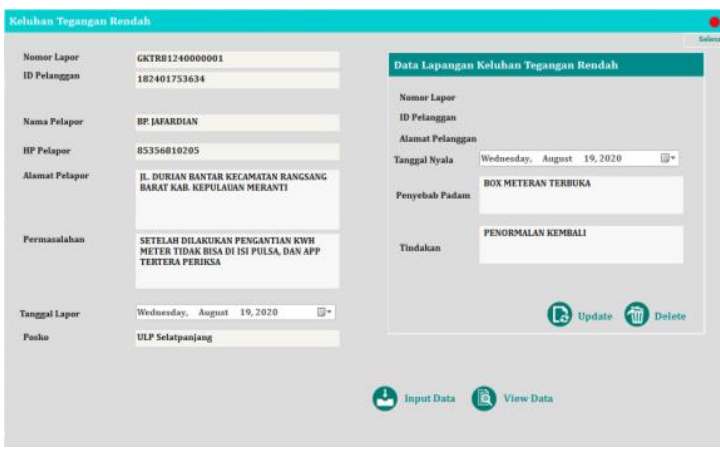

\section{Gambar 8. Tampilan Data Lapangan} Keluhan Aktif Rendah

\section{Tampilan Historis}

Form transaksi historis merupakan form yang digunakan untuk menampilkan keseluruhan data pengaduan baik gangguan maupun keluhan dari tabel gangguan tegangan rendah, gangguan tegangan menengah, keluhan tegangan rendah dan gangguan khusus, Form transaksi historis dapat dilihat pada Gambar 9. 


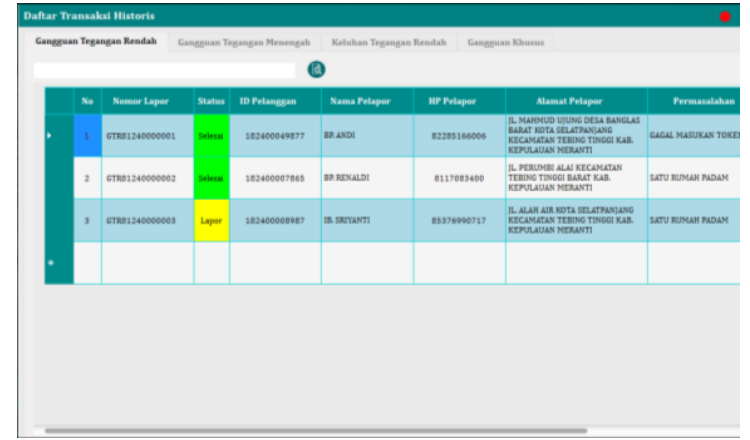

Gambar 9. Tampilan Historis

\section{Tampilan Cetak Pengaduan \\ Gangguan Tegangan Rendah}

Form cetak pengaduan gangguan tegangan rendah merupakan form yang digunakan untuk menampilkan keseluruhan data pengaduan gangguan dari tabel gangguan tegangan rendah, gangguan tegangan menengah, keluhan tegangan rendah dan gangguan khusus, Form cetak pengaduan gangguan tegangan rendah dapat dilihat pada Gambar 10.

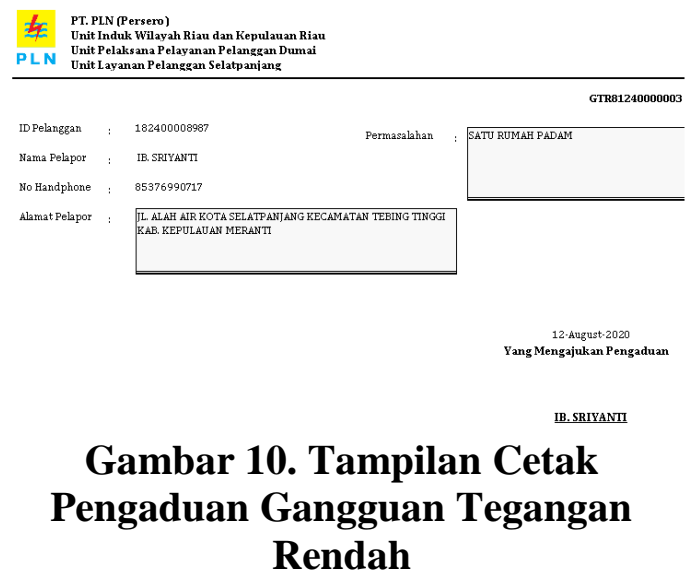

\section{Tampilan Cetak Pengaduan Keluhan Tegangan Rendah}

Form transaksi cetak pengaduan keluhan tegangan rendah merupakan form yang digunakan untuk menampilkan keseluruhan data pengaduan keluhan dari tabel gangguan tegangan rendah, gangguan tegangan menengah, keluhan tegangan rendah dan gangguan khusus, Form transaksi cetak pengaduan keluhan tegangan rendah dapat dilihat pada Gambar 11.

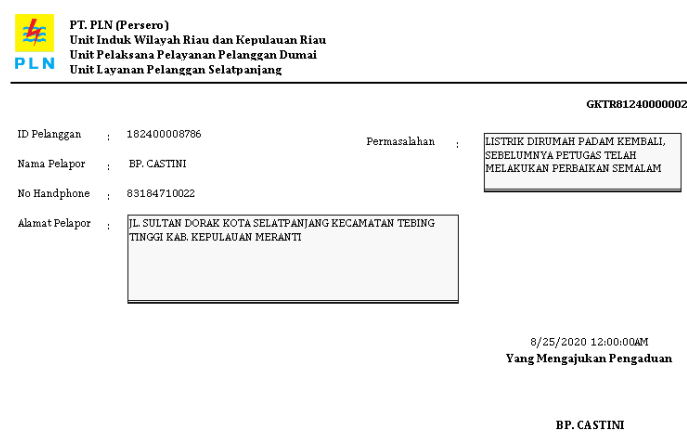

Gambar 11. Tampilan Cetak Pengaduan Keluhan Tegangan Rendah

\section{Tampilan Rekap Data Gangguan Tegangan Rendah}

Form transaksi rekap data gangguan tegangan rendah merupakan form yang digunakan untuk menampilkan keseluruhan data pengaduan gangguan dari tabel gangguan tegangan rendah, gangguan tegangan menengah, keluhan tegangan rendah dan gangguan khusus, Form transaksi rekap data gangguan tegangan rendah dapat dilihat pada Gambar 12.

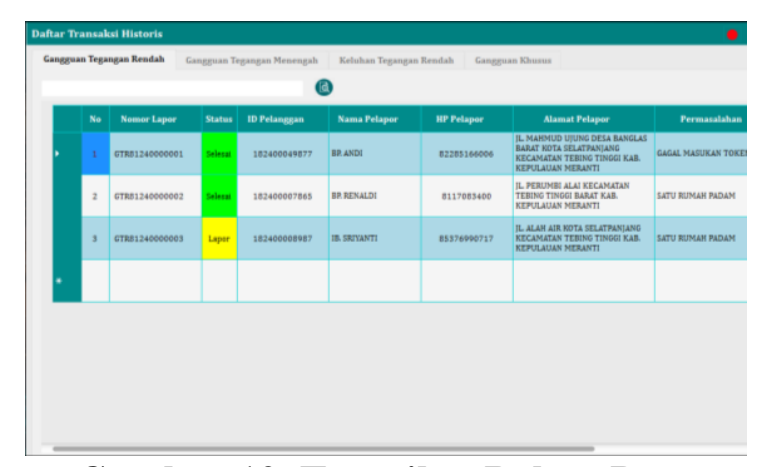

\section{Gambar 12. Tampilan Rekap Data Gangguan Tegangan Rendah}

\section{Tampilan Rekap Data Keluhan Tegangan Rendah}

Form transaksi rekap data keluhan tegangan rendah merupakan form yang digunakan untuk menampilkan keseluruhan data pengaduan keluhan dari tabel gangguan tegangan redah, gangguan tegangan menengah, keluhan tegangan rendah dan gangguan khusus, Form transaksi rekap data keluhan tegangan rendah dapat dilihat pada Gambar 13. 


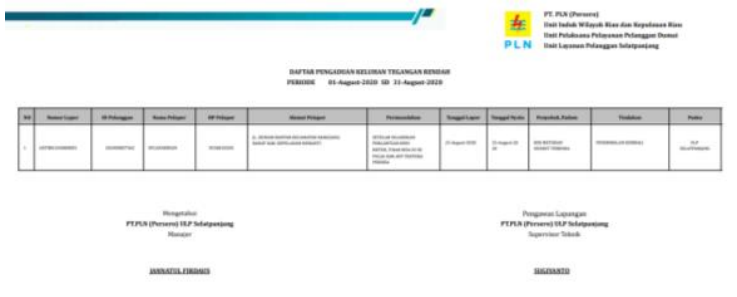

Gambar 13. Tampilan Rekap Data Keluhan Tegangan Rendah

\section{KESIMPULAN}

Berdasarkan pembahasan yang penulis uraikan tentang system informasi pencatatan pengaduan dan keluhan di unit layanan pelanggan PT. PLN Selatpanjang, penerapan sistem informasi pencatatan pengaduan dan keluhan di PT. PLN Unit Layanan Pelanggan Selatpanjang yang masih menggunakan pencatatan secara manual, maka PT. PLN Unit Layanan Pelanggan Selatpanjang memerlukan aplikasi agar penyimpanan data lebih aman dan mudah ditemukan apabila dibutuhkan. Sistem yang terkomputerisasi memberi kemudahan bagian operator dan admin dalam melakukan pencatatan pengaduan dan keluhan sehingga mempermudah bagian operator dan admin dalam mengolah data, membuat laporan pengaduan, laporan rekap gangguan dan menemukan setiap gangguan yang telah di input jika sewaktu-waktu terdapat kekeliruan dalam pencatatan gangguan dan keluhan tersebut, selain itu juga akan memperkecil resiko kehilangan data akibat dari penggantian karyawan.

\section{DAFTAR PUSTAKA}

\section{Subtari, Tata. (2004). Analisa Sistem}

Informasi. Yogyakarta: C.V Andi Offset.

Ineke, Pakereng, M.A., Teguh Wahyono.
(2004).
Sistem
Basis Data
(Konsep dan Pendekatan
Praktikum). Yogyakarta: Graha Ilmu

Subagia, Anton. (2017). Membangun

Aplikasi dengan Condeigniter dan Database SQL Server. Jakarta: PT Elex Media Komputindo Kelompok Gramedia

Afyenni, Rita. (2014). Perancangan Data Flow Diagram Untuk Sistem Informasi Sekolah (Studi Kasus Pada SMA Pembangunan Laboratorium UNP). Jurnal TEKNOIF, 2(1), 35-39

Rustamin, Zulvianita, Anita Puspita Dewi. (2016). Sistem Pengarsipan Surat Masuk Dan Surat Keluar Pada Kantor Sekretariat Dprd Provinsi Sulawesi Tenggara Menggunakan Borland Delphi 7. Jurnal Sistem Informasi Dan Teknik Komputer, 1(2), 165-172.

Wadisman. (2018). Perancangan

Aplikasi Pengolahan Data Logistik Pada Kantor Cabang Bri Solok. Journal of Information Technology and Computer Science, 1(2), 140-150.

Wahyuni, Nur Laila. (2011). Sistem

Informasi Pengolahan Data Inventory Pada Toko Buku Studi Cv. Aneka Ilmu Semarang. Jurnal Teknik Elektro, 3(1), 40-55.

Ismael. (2017). Rancang Bangun Sistem Informasi Penyaluran Semen Padang Untuk Daerah Bengkulu Selatan Di Cv. Mutia Bersaudara. Jurnal EdikInformatika, 3(2), 147-156. 